\title{
Evaluation of Performance and Potential Development of Local Sheep in Kaliangkrik District
}

\author{
Nur Rasminati and Setyo Utomo \\ Departement of Animal Husbandry, Faculty of Agroindustry, Mercu Buana University, Yogyakarta 55753, Indonesia
}

\begin{abstract}
This study aimed to evaluate the performance and potential of development local sheep in sub-district Kaliangkrik. Respondents were taken from sheep farmers in the village Munggangsari and Wonocoyo with the number of livestock ownership of at least two tails. This study used a survey method, with sampling of respondents in the census. The results showed the average number of sheep ownership as much as 0.47 animal units (AU) with a range of 0.14 AU to $1.15 \mathrm{AU}$. The largest population structure is lamb (25.66\%), ewe (23.03\%), ram (18.61\%), ram lamb (16.92\%) and ewe lamb (15.79\%). Sex ratio of ram: ewe is 1:1.5 for adult sheep and 1:1.2 for lambs. Weight of ram is $26.75 \mathrm{~kg}$ and ewes $26.37 \mathrm{~kg}$; weight of male lamb is $8.42 \mathrm{~kg}$, with average daily gain (ADG) $48.11 \mathrm{~g} / \mathrm{head} / \mathrm{day}$, while the female lamb $6.61 \mathrm{~kg}$ with ADG $44.13 \mathrm{~g} / \mathrm{head} / \mathrm{day}$. The average sheep lambing interval was 8.4 months, with an average litter size of 1.3 tails. Based on the calculation of the adequacy of feed, the obtained level of sufficiency (feed production ratio and feed requirement) is 1.89 , which means the area has adequate feed production. It was concluded that sheep productivity was good enough and potentially to be developed in Kaliangkrik region.
\end{abstract}

Key words: Production performance, local sheep, adequacy of the feed, sub-district Kaliangkrik.

\section{Introduction}

The development of farm sheep is constrained on the provision of superior breeds. One of the important parameter that should be considered in selecting livestock, especially for meat producers is the relatively high proliferation and growth. To realize the success of sheep farming, a good management is required, such as breeding management. To improve the productivity of sheep farming, the effort that can be done is improving the quality of breeds and feed.

Commonly, the sheep breeding system in Indonesia is done traditionally by feeding, which is still dependent on the available forage, only small amount or even no concentrate [1-3]. It causes that the live weight and the increase of body weight of sheep in small farmers in rural areas are low, i.e., $23 \mathrm{~kg}$ and 32 g/d [4].

Kaliangkrik is one of sub-district in Magelang, located in the slopes of Sumbing Mountain, which has

Corresponding author: Nur Rasminati, M.Sc., research fields: livestock production, feed technology.
20 villages with total area of $57.34 \mathrm{~km}^{2}$, the distance to the district capital $30 \mathrm{~km}$ and the height from the sea level $823 \mathrm{~m}$.

The population of livestock in Kaliangkrik in 2007-2010 condition is 1,942 beef cattles, 260 buffaloes, five horses and 8,835 sheeps. Meat production of cattle is $57,369 \mathrm{~kg}$, goat $31,076 \mathrm{~kg}$ and sheep 91,909 kg [5].

The potential of Kaliangkrik sub-district as a forage producer is very abundant, with forage production of 100 tons/ha. Defoliation with natural grassland contained in every part of the land area of moorland, yard and rice field makes the sheep growing rapidly in this region.

The availability of forage is abundant, along with agricultural waste products whose production is almost throughout the year, and the socio-cultural conditions of people who prefer sheep to other livestock, causing sheep to grow rapidly.

The development of sheep in Kaliangkrik sub-district is also supported by the existence of Kaliangkrik animal market. Average sheep ownership 
of 3-4 head/household with the average sheep out of this region around 50-75 head/month, indicating the trading system of sheep in the region has run smoothly, although there has been no touch of cultivation technology [6].

Based on the potential in Kaliangkrik sub-district, this research was done to evaluate the performance and potential development of local sheep in Kaliangkrik sub-district to make this area a resource of high quality sheep breeds.

This research aimed to evaluate the potential area for the development of sheep and gain information about sheep production performance in Kaliangkrik sub-district.

\section{Research Methods}

The study was conducted in two villages with the largest population of sheep, which are Munggangsari and Wonocoyo village, using survey method. The sample is determined based on $10 \%$ of the population with the criteria of the total number of ownership of at least two sheep and has food crops both around the house, yard or rice field/land.

There were 60 respondents used as research samples. The data obtained consist of primary and secondary data. At this stage, primary data were obtained through direct interview with the respondents, including farmers' identity, which was done directly using questionnaire prepared. The secondary data taken are total sheep population in Kaliangkrik sub-district.

Data taken consist of average feed production, agricultural waste utilized for sheep feed and livestock productivity during the study, which includes livestock weight, breeding distance and average birth rate per year.

The data obtained were tabulated, averaged and then analyzed descriptively [7].

\section{Results and Discussion}

\subsection{General Condition of Farmers}

Reviewed from the age characteristic, farmers are in age range of 23-43 years old with average 35.5 years old (Table 1). At this age, respondents are still within the range of productive age, so they are expected to have the strength and ability to manage agriculture field and farms better in order to produce the maximum possible output.

Examined from the age characteristic above, the most farmers are in productive age category. Age factor is usually identified by work productivity and if someone is in productive age, there is also high productivity tendency. The younger the age of the farmer (productive age is 20-45 years old), generally the sense of curiosity towards something is higher and the interest to adopt towards technology introduction is higher, too [8].

Age of farmers will greatly affect the mobility of farmer in raising livestock, the younger it will be more agile, so it is expected that farmers who are in young age and productive will be able to keep the livestock well and livestock productivity will increase.

Viewed from the experience of breeding, farmers in the research location have about 11.6 years' experience. This indicates that farmers are mature enough in raising livestock. Breeding experiences will affect the habits done related to livestock management.

All respondents work as farmers (100\%). The result of the interviews showed that none of the respondents stated that their main livelihood was farmers or breeder. However, farmers seem to consider sheep farming as one source of income other than as savings.

The purpose of raising sheep $100 \%$ is to add the income. This is different from the result of study of Budisatria [9], who found that sheep/goat farming was not feasible to be used as main livelihood and considered as a sideline and saving that can be sold at

Table 1 Identity of sheep breeder.

\begin{tabular}{ll}
\hline Parameter & Survey result \\
\hline Average age (years) & 35.5 \\
Farmer (\%) & 100 \\
Average length of breeding (years) & 11.6 \\
Average number of livestock (animal units; AU) & 0.47 \\
The purpose of raising: increase revenue (\%) & 100 \\
\hline
\end{tabular}


any time. The difference may be due to local conditions. The result of study [10] shows that Gunungkidul, especially GiriSekar is a very dry area and close to the forest, so that goat farming is the main income for the family there. This is supported by the high mutation of livestock that happens every month.

Average number of sheep ownership is $0.47 \mathrm{AU}$ with the range 0.14-1.15 AU. The largest population structure is lamb (25.66\%), ewe (23.03\%), ram (18.61\%), ram lamb (16.92\%) and ewe lamb (15.79\%). It can be understood because the purpose of raising sheep is to produce breeds, so that the largest composition is ewe and lamb.

Sex ratio of ram: ewe is 1:1.5 for adult sheep and 1:1.2 for lambs. Based on these ratios, for the purpose of reproduction or development, it will not become a serious problem because the ideal ratio of ram: ewe is 1:8 [11]. This indicates that in the study location, there is no new ram required.

\subsection{Maintenance Management}

All farmers (100\%) have not used a stage pen to raise sheep yet; they still use ground floor pens. Livestock are also kept in individual pen. According to farmers, stage pen and individual system require relatively high cost, although according to the respondents, they are easier in diseases management and control. However, due to the limited fund and number of livestock, they prefer to use the ground floor for livestock.

Farmers who use the ground floor stated that this system cause the rest of feed be mixed directly with faeces, so that if it continues to accumulate, it will produce enough compost. In fact, almost all farmers never clean the pen regularly. The existence of the remaining feed left is also intended as a pen base, so that the pen remains dry even on the ground floor.

Although the pen is not cleaned regularly, farmers stated that this condition has no impact on sheep health, and based on the available note, there is no death case or sick livestock caused by the pen which is rarely cleaned. This is probably due to the pen ground, which is kept dry.

The feed given to sheep is generally in form of forage and concentrate feed. The forage given comes from field grass, superior grass (elephant grass (pennisetum purpureum), king grass (pennisetum purpuroides)) and calliandra, which is grown in grassland area owned by farmers and marginal land, such as rice field or agricultural land. The forage given by farmers is as much as 4-6 kg/head/day, and it is given twice a day (morning and evening). In addition, farmers also give corn stalks, groundnut straw, cassava leaves, as the substitute of forage (in the harvest season) and other plants, such as Calliandra leaves, Glirisidae, waru leaves, kelor leaves and mindi leaves [12].

All farmers give concentrate to their livestock. Concentrate is given in form of rice bran, corn bran, polard, corn cob and klobot with the amount of giving ranged from $0.3 \mathrm{~kg} / \mathrm{head} /$ day to $0.5 \mathrm{~kg} / \mathrm{head} /$ day. Provision of mineral is also done by farmers in form of salt dissolved in drinking water, and through the provision of forage to increase appetite. Especially for additional feed, breeders already provide silage preserved feed made by the farmers in form of silage using local microbial starter. The type of feed given by the farmer can be seen in Table 2 .

The feeding model is based on the availability of feed in mountainous areas dominated by reforestation plants to maintain erosion, such as Calliandra and lamtoro, etc.. Farmers will give the feed to their livestock based on the availability of abundant feed in their area. The research location is a corn producing area, so that the use of corn crop waste as livestock

Table 2 The kind of feed given.

\begin{tabular}{ll}
\hline Forage type & Percentage (\%) \\
\hline Grass field & 25.00 \\
Elephant grass & 18.75 \\
Calliandra & 18.75 \\
Corncob & 12.50 \\
Cassava leaves & 15.00 \\
“Klobot” & 10.00 \\
\hline
\end{tabular}


feed is very high.

The abundant availability of feed is due to the research location, which is adjacent to the forest, so that the farmers will get the source of high quality feed easily. The diversity in the supply of feed, feeding and management affects the efficiency of the conversion of food by the parent [13].

Based on the quantity, forage feed and forage reinforcement feed given are as much as 5.95 $\mathrm{kg} / \mathrm{head} /$ day. The concentrate is $0.21 \mathrm{~kg} / \mathrm{head} / \mathrm{day}$. Based on it, the amount of forage given to the sheep in Kaliangkrik is enough, because it already exceeds $10 \%$ of body weight, similarly for the provision of concentrates.

\subsection{Sheep Production}

The performance of meat production can be measured by the weight at a time or phase and daily weight gain (Table 3).

The result showed that the body weight of ram was $26.75 \mathrm{~kg}$, while for ewe was $26.37 \mathrm{~kg}$. This body weight is within the range of research results [14] that is $20-30 \mathrm{~kg}$. The body weight of this research is higher than the result of research [15], which stated that the weight of adult sheep is about $22 \mathrm{~kg}$. However, the standard sets for adult livestock (one year old) is that it should have a body weight of $35-40 \mathrm{~kg}$, while in fact, goat and sheep at this age generally have weight of $20-30 \mathrm{~kg}$.

While for lamb category, the body weight of male is $8.42 \mathrm{~kg}$ with average daily gain (ADG) 48.11 $\mathrm{g} /$ head/day and female $6.61 \mathrm{~kg}$ with ADG 44.13 $\mathrm{g} /$ head/day (Table 3). Based on the result of research [16], sheep, which is given elephant grass feed and lamtoro leaves, have ADG of $35-57 \mathrm{~g} / \mathrm{head} / \mathrm{day}$, elephant grass and cassava leaves have ADG 33-59 g/head/day, and elephant grass have ADG 20-35 $\mathrm{g} /$ head/day, higher than the result of research [17], which is $27 \mathrm{~g} /$ head/day. According to Mathius et al. [18], one of the factors that affect the growth rate is feed. Furthermore, it is stated that the need of food substances is very dependent on sex, physiological status of livestock, life weight and level of expected daily body weight.

Besides growth, the performance of sheep's reproduction observed is the distance of birth (lambing interval) and litter size (Table 4).

Based on the result of research, the average lambing interval of sheep in the research area is 8.4 months with average litter size 1.3 head. The result of ideal lambing interval calculation is eight months (in two years can give birth three times), which is five months of pregnancy and three months estrous and mating and pregnant. According to Iniguez et al. [15], thin tail sheep in Sumatra shows the range of birth is about 160-260 d (5-8 months) with average $201 \pm 30 \mathrm{~d}$ or can bear 1.82 times per year, so it can produce 3.6 lambs/year with total weaning weight $31.9 \mathrm{~kg}$ per 22 $\mathrm{kg}$ body weight of ewe. Based on the study of Haryanto et al. [14], sheep and goat lambing interval in Indonesia ranged in 7.44 months for thin tail sheep and 8.16 for thick tail sheep, and according to Sutama et al. [19], the sheep interval of birth is 7-8 months.

Based on it, the lambing interval in research location is ideal. Lambing interval is affected by the long pregnancy, post partum estrous and service per conception [20] and mating-management.

\subsection{Sufficiency of Feed}

Besides requiring fibrous feed from forage as an

Table 3 Average weight (kg) and ADG (g/head/day) of sheep at various phase.

\begin{tabular}{lllcl}
\hline Phase & Male & ADG & Female & ADG \\
\cline { 1 - 2 } Adult & 26.75 & - & 26.37 & - \\
Young & 18.04 & 35.70 & 18.72 & 32.40 \\
Lamb & 8.42 & 48.11 & 6.61 & 44.13 \\
\hline
\end{tabular}

Table 4 Performance of sheep reproduction in Kaliangkrik sub-district.

\begin{tabular}{ll}
\hline Parameter & Survey result \\
\hline First mating (month) & 12.6 \\
First lambing (month) & 16.7 \\
Lambing interval (month) & 8.4 \\
Post partum mating (d) & 96.7 \\
\hline
\end{tabular}


energy source, sheep feed also needs reinforcing feed as protein source which functioned to complete the nutrients derived from forage [21]. It will complement the needs of livestock nutrition in a balanced and sufficient way. Based on the result of the research, it is known that the awareness of sufficient and balance feeding needs to be improved and maintained in order to get more optimal sheep productivity.

Based on the results of the research, it is known that the production of forage in Kaliangkrik is 11,348 $\mathrm{kg} /$ year and the feed requirement is 6,004.25 kg/year, so the sheep feed sufficiency value is 1.89 . It can be stated that the sufficiency of feeding based on the quantity of forage in Kaliangkrik is above the sufficient limit (value above 1).

The sheep productivity level is influenced by the feed condition, through the improved management; the productivity will increase [22]. One of the factors affecting the growth rate is feed. The fact shows that to grow and develop livestock must get the nutrients supply/nutrition from feed. Feed should be able to provide the food substances used to replace the damaged and dead parts of the body and can provide the energy to grow and develop [18].

If viewed from the time of the research activity in the dry season, sheep feed can be fulfilled because of the annual plants that produce forage for sheep. In addition, farmers have begun the technology of feed preservation in the form of silage, so that the need of feed for sheep can be fulfilled.

\section{Conclusions}

Based on the result of this study, it can be concluded that production and reproduction performance for sheep in Kaliangkrik are good, in terms of body weight, ADG, both in lamb, young lamb and adult and lambing interval. In general, Kaliangkrik region has a potential for developing sheep farming with the sufficiency of feed 1.86 .

\section{References}

[1] Devendra, C. 1993. "Goat and Sheep in Asia.” In Goat and Sheep Production in Indonesia, edited by Wodzicka-Tomaszewska, M., Mastika, I. M., Djajanegara, A., Gardiner, S., and Wiradarya, T. R. Surakarta: Sebelas Maret University Press. (in Indonesian)

[2] Haryanto, B., and Djajanegara, A. 1993. "Fulfilling the Needs Nutrients of Small Ruminants.” In Goat and Sheep Production in Indonesia, edited by Tomaszewska, M. W., Mastika, I. M., Djajanegara, A., Gardiner, S., and Wiradaya, T. R. Surakarta: Sebelas Maret University Press, 159-208. (in Indonesian)

[3] Mathius, L. W. 1989. "The Types and Nutritional Value of Forage for Sheep and Goat in Rural West Java.” In Proceeding of Ruminant Scientific Meeting, Vol. 2. Departement of Agriculture, Livestock Research and Development Center, Agricultural Research and Development Agency, Bogor. (in Indonesian)

[4] Sabrani, M., and Levine, J. M. 1993. "Approach of Agricultural System for Small Ruminant Production.” In Goat and Sheep Production in Indonesia, edited by Tomaszewska, M. W., Mastika, I. M., Djajanegara, A., Gardiner, S., and Wiradaya, T. R. Surakarta: Sebelas Maret University Press. (in Indonesian)

[5] Central Bureau of Statistics Kaliangkrik District. 2014. The Population of Livestock in Kaliangkrik. (in Indonesian)

[6] Rasminati, N. 2012. Potential Analysis of Kaliangkrik Sub-district for the Development of Beef Cattle. Independent Research Report, University of Mercu Buana Yogyakarta. (in Indonesian)

[7] Sugiyono, B. 1999. Statistics for Research. Bandung: CV Alfabeta. (in Indonesian)

[8] Chamdi, A. N. 2003. "Review of Socio-economic Profile of Goat Business in Kradenan Sub-district Grobogan District." In Proceedings of National Seminar on Livestock and Veterinary Technology, 312-7. (in Indonesian)

[9] Budisatria, I. G. S. 2006. "Dynamics of Small Ruminant Development in Central Java Indonesia.” Ph.D. thesis, Wageningen Agriculture University, Wageningen, the Netherlands.

[10] Murdjito, G., Budisatria, I. G. S., Panjono, Ngadiyono, N., and Baliarti, E. 2011. "Performances of Bligon Goats Kept by Farmers at Giri Sekar Village, Panggang, Gunung Kidul.” Livestock Bulletin 35 (2): 86-95. (in Indonesian)

[11] Utomo, S., and Supriyadi. 1994. Study of Potential of Etawah Goat Breeder (PE) in Kulon Progo Regency. Research Report, Wangsa Manggala Foundation, Wangsa Manggala University, Yogyakarta. (in Indonesian)

[12] Rasminati, N. 2011. Potential of Coastal Areas of Wates District for Development of Etawah Crossbred Goats in Kulon Progo. Research Report, University of Mercu 

in Kaliangkrik District

Buana Yogyakarta. (in Indonisian)

[13] Devendra, C., and Burns, M. 1994. Sheep Production in the Tropics. Bandung: ITB Publisher. (in Indonesian)

[14] Haryanto, B., Inounu, I., and Sutama, I. K. 1997. "Availability and Needs of Production Technology of Goat and Sheep.” Presented at National Seminar on Animal Husbandry and Veterinary, Animal Husbandry Research Institute, Bogor. (in Indonesian)

[15] Iniguez, L., Sanchez, M., and Ginting, S. P. 1991. "Productivity of Sumatran Sheep in a System Integrated with Rubber Plantation.” Small Ruminant Research 5 (4): 303-17.

[16] Johnson, W. L., and Djajanegara, A. 1989. “A Pracmatic Approach to Improving Small Ruminant Diets in the Indonesian Humid Tropics.” J. Anim. Sci. 67 (11): 3068-79.

[17] Chaniago, T. D., Obst, J. M., Parakkasi, A., and Winugroho, M. 1984. "Growth of Indonesian Sheep under Village and Improved Management System." Science and Animal Husbandry 1 (6): 231-7.

[18] Mathius, W. I., Martawidjaja, M., Wilson, A., and
Manurung, T. 1996. "Study of Energy Needs Strategy_Protein for Local Sheep: Part 1, Growth Phase.” Journal of Animal and Veterinary Science 2 (2): 84-91. (in Indonesian)

[19] Sutama, I. K., Budiarsana, I. G. M., and Saefudin, Y. 1995. "Reproductive Performance around Puberty and First Partum of Etawah Peranakan Goat.” Journal of Animal and Veterinary Science 8 (1): 9-12. (in Indonesian)

[20] Salisbury, G. W., and VanDemark, N. L. 1985. Physiology of Reproduction and Artificial Insemination of Cattle, translated by Djanuar, R. Yogyakarta: Gadjah Mada University Press. (in Indonesian)

[21] Wodziscka-Tomaszewska, M., Djajanegara, A., Garner, S., Wiradaryadan, T. R., and Mastika, I. M. 1993. Goat and Sheep Production in Indonesia. Surakarta: UNS Press. (in Indonesian)

[22] Inounu, I., Iniguez, L., Bradford, G. E., Subandriyo, and Tiesnamurti, B. 1993. "Production Performance of Prolific Javanese Ewes.” Small Ruminant Research 12 (3): 243-57. 